\title{
Вопросы разработки технического задания на проектирование объектов капитального строительства предприятий радиоэлектронной промышленности
}

\author{
Е. Луковка ${ }^{1}$
}

\begin{abstract}
В рамках Государственной программы Российской Федерации "Развитие электронной и радиоэлектронной промышленности на 2013-2025 годы" Департамент радиоэлектронной промышленности Минпромторга России определил четыре приоритетных направления развития отрасли: телекоммуникационное оборудование, вычислительная техника, системы интеллектуального управления и специальное технологическое оборудование. При реализации проектов в этих сферах перед предприятиями радиоэлектронной отрасли возникают вопросы, связанные с техническим перевооружением, реконструкцией и строительством. Данная проблематика лежит в основе работы служб главных инженеров производств, заместителей директоров по техническому перевооружению и развитию производств. Ключевое условие успешного выполнения этих задач - правильное составление технического задания на проектирование объектов технического перевооружения, реконструкцию или создание нового производства.
\end{abstract}

ля разработки проектной документации в соответствии со ст. 48 Градостроительного кодекса РФ и ст. 759 Гражданского кодекса РФ необходимы исходные данные, которые предоставляются заказчиком вместе с заданием на проектирование. Основной перечень исходных данных, относящихся ко всем объектам строительства, определен п. 10 б Положения, утвержденного Постановлением Правительства РФ от 16 февраля 2008 года № 87. В этот перечень входят следующие документы:

- задание на проектирование - в случае подготовки проектной документации на основании договора;

- отчетная документация по результатам инженерных изысканий;

- правоустанавливающие документы на объект капитального строительства - в случае подготовки проектной документации для реконструкции или капитального ремонта объекта капитального строительства;

- утвержденный и зарегистрированный в установленном порядке градостроительный план земельного

ОАО «СТЭП», генеральный директор, тел. / факс: +7 (8652) 94-40-35, step@oboron77.ru. участка, предоставленного для размещения объекта капитального строительства;

- документы об использовании земельных участков, на которые действие градостроительных регламентов не распространяется или для которых градостроительные регламенты не устанавливаются, выданные в соответствии с федеральными законами уполномоченными федеральными органами исполнительной власти, или уполномоченными органами исполнительной власти субъектов Российской Федерации, или уполномоченными органами местного самоуправления;

- технические условия, предусмотренные ч. 7 ст. 48 Градостроительного кодекса РФ и иными нормативными правовыми актами, если функционирование проектируемого объекта капитального строительства невозможно без его подключения к сетям инженерно-технического обеспечения общего пользования;

- документы о согласовании отступлений от положений технических условий;

- разрешение на отклонения от предельных параметров разрешенного строительства объектов капитального строительства; 
- акты (решения) собственника здания (сооружения, строения) о выведении из эксплуатации и ликвидации объекта капитального строительства - в случае сноса (демонтажа);

- иные исходно-разрешительные документы, установленные законодательными и иными нормативными правовыми актами Российской Федерации, в том числе техническими и градостроительными регламентами;

- решение органа местного самоуправления о признании жилого дома аварийным и подлежащим сносу - при необходимости сноса жилого дома;

- обоснование безопасности опасного производственного объекта в случаях, предусмотренных ч. 4 ст. 3 Федерального закона "О промышленной безопасности опасных производственных объектов", и положительное заключение экспертизы промышленной безопасности такого обоснования, внесенное в реестр заключений экспертизы промышленной безопасности.

Уточненный перечень исходных данных определяется применительно к каждому конкретному объекту капитального строительства в зависимости от его функционального назначения, места размещения земельного участка, геологических, природно-климатических и других аналогичных условий в соответствии с действующим законодательством.

сбор исходных данных может быть поручен проектировщику. Стоимость работ по сбору исходных данных - предмет договора между заказчиком и проектировщиком.

Согласно ст. 26 Земельного кодекса РФ от 25 октября 2001 года № 136-Ф3, «права на земельный участок, предусмотренные главами III и IV настоящего Кодекса, удостоверяются документами в соответствии с Федеральным законом от 21 июля 1997 года № 122-Ф3 «О государственной регистрации прав на недвижимое имущество и сделок с ним".

Кроме того, необходимо учитывать следующие положения:

- виды разрешенного использования земельных участков устанавливаются в соответствии с положениями ст. 37 Градостроительного кодекса РФ от 29 декабря 2004 года № 190-Ф3;

- состав и порядок документов для перевода земель или земельных участков в составе таких земель из одной категории в другую должен соответствовать положениям ст. 2 Федерального закона от 21 декабря 2004 года № 172-Ф3 «О переводе земель или земельных участков из одной категории в другую»;

- перечень документов, прилагаемых к заявлению о приобретении прав на земельный участок, который находится в государственной или муниципальной собственности и на котором расположены здания, строения, сооружения, подготавливается в соответствии с приказом Минэкономразвития России от 30 октября 2007 года № 370;

- правила возмещения собственникам земельных участков, землепользователям, землевладельцам и арендаторам земельных участков убытков, причиненных изъятием или временным занятием земельных участков, ограничением прав собственников земельных участков, землепользователей, землевладельцев и арендаторов земельных участков либо ухудшением качества земель в результате деятельности других лиц, установлены Постановлением Правительства РФ от 07 мая 2003 года № 262.

Понятие «Исходные данные для выполнения проектных и изыскательских работ" законодательно зафиксировано в ст. 759 Гражданского кодекса РФ. Указанной статьей установлено:

«1. По договору подряда на выполнение проектных и изыскательских работ заказчик обязан передать подрядчику задание на проектирование, а также иные исходные данные, необходимые для составления технической документации. Задание на выполнение проектных работ может быть по поручению заказчика подготовлено подрядчиком. В этом случае задание становится обязательным для сторон с момента его утверждения заказчиком

2. Подрядчик обязан соблюдать требования, содержащиеся в задании и других исходных данных для выполнения проектных и изыскательских работ, и вправе отступить от них только с согласия заказчика».

В комментариях к приведенной статье Гражданского кодекса РФ указано: "Задание на проектирование характеризуется как разновидность исходных данных. Это не вполне точно. В нормативных документах различаются рекомендуемый состав и содержание задания на проектирование, основные данные и требования к нему и исходные материалы, передаваемые подрядчику вместе с заданием на проектирование. По общему правилу задание и исходные материалы готовит заказчик. В то же время эту документацию по поручению заказчика может подготовить подрядчик».

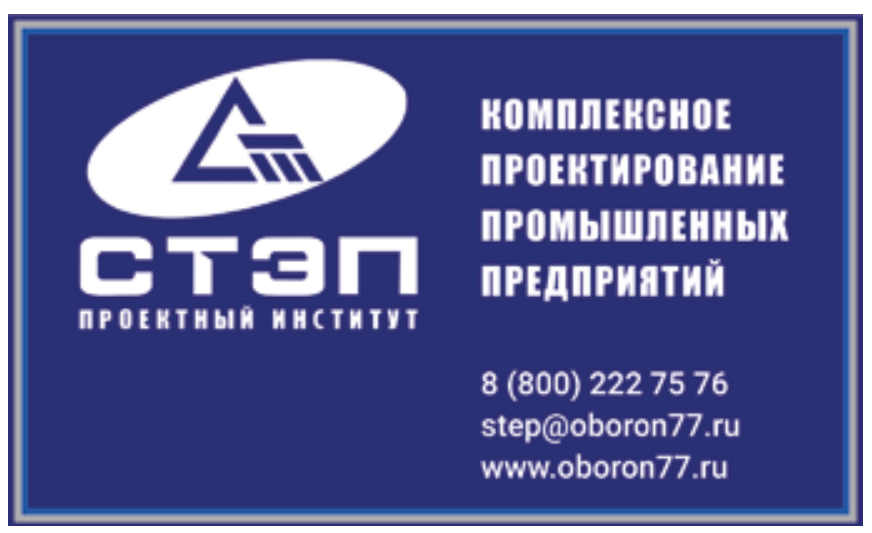


Указанную точку зрения разделяют и специалисты ОАО "СтЭП". Обоснованность такого мнения можно найти в 4. 5 ст. 48 Градостроительного кодекса РФ, устанавливающей, что "договором о подготовке проектной документации может быть предусмотрено задание на выпопнение инженерных изысканий, обеспечение технических условий".

Однако технические условия - один из документов, содержащих исходные данные и требования для архитектурно-строительного проектирования. Таким образом, сбор исходных данных и исходно-разрешительной документации может быть на договорной основе поручен заказчиком подрядчику по проектированию (проектировщику). Вместе с тем эта работа - функция заказчика, которая не учтена сборниками цен на проектные работы, поэтому должна оплачиваться отдельно.

Состав и содержание исходных данных, исходно-разрешительной документации в значительной мере зависят от функционального назначения объекта капитального строительства, его мощностных параметров и места размещения, геологических, экологических, санитарно-эпидемиологических условий в регионе, стадии проектирования, на которой осуществляется их сбор, и других аналогичных факторов.

Практика показывает, что в процессе предпроектной и проектной подготовки строительства заказчик должен предоставить от 80 до 200 исходных данных и исходно-разрешительных документов, требуемых для архитектурно-строительного проектирования.

Таким образом, сбор исходных данных и исходноразрешительных документов - процесс, который осуществляется на протяжении всего периода проектирования и строительства. На это обстоятельство указывают, в частности, положения ст. 12 Федерального закона от 17 ноября 1995 года № 169-Ф3 «Об архитектурной деятельности в Российской Федерации»:

"Архитектор и юридическое пицо на основании договора с заказчиком (застройщиком) имеют право:

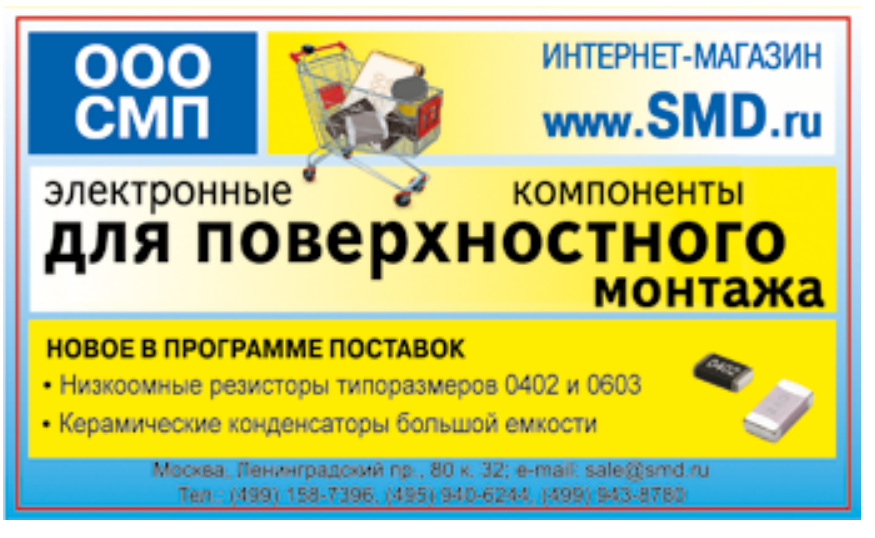

запрашивать и получать от соответствующих органов архитектурно-планировочное задание, иные сведения и исходные документы, необходимые для предпроектных исследований, проектирования и строительства архитектурного объекта».

Получение некоторых документов возможно только в процессе проектирования после подготовки исходных данных, требуемых для запроса.

Так, для получения «технических условий подключения" объекта капитального строительства к сетям инженерно-технического обеспечения правообладатель земельного участка в соответствии с п. 8 Правил определения и предоставления технических условий подключения объекта капитального строительства к сетям инженерно-технического обеспечения, утвержденных Постановлением Правительства РФ от 13 февраля 2006 года № 83, должен в запросе указать:

"необходимые виды ресурсов, получаемых от сетей инженерно-технического обеспечения";

«планируемую величину необходимой подкяючаемой нагрузки (при наличии соответствующей информации)».

\section{ЗАКЛЮЧЕНИЕ}

При сборе исходных данных, исходно-разрешительной документации заказчик может действовать как самостоятельно, без участия проектировщика, так и использовать сведения, содержащиеся в проектной документации, подготовленной проектировщиком.

После отмены СНиП 11-01-95 «Инструкция о порядке разработки, согласования, утверждения и составе проектной документации на строительство предприятий, зданий и сооружений" (Постановлением Госстроя России от 17 февраля 2003 года №18) состав задания на разработку проектной документации в отношении объектов капитального строительства различного назначения в настоящее время не регламентирован. При составлении задания на разработку проектной документации следует учитывать положения п. 14 Правил проведения проверки инвестиционных проектов на предмет эффективности использования средств федерального бюджета, направляемых на капитальные вложения, утвержденных Постановлением Правительства РФ от 12 августа 2008 года № 590.

Состав задания на разработку рабочей документации не устанавливается.

Согласно п. 2 ст. 743 Гражданского кодекса РФ, «договором строительного подряда должны быть определены состав и содержание технической документации, а также должно быть предусмотрено, какая из сторон и в какой срок должна предоставить соответствующую документацию". К составлению задания на разработку рабочей документации следует подходить с учетом данного законодательного положения. 


\section{interlight | intelligent building}

RUSSIA

RUSSIA

Международная выставка освещения,

систем безопасности, автоматизации зданий

и электротехники

\section{0-13 сентября 2019}

ЦВК «Экспоцентр» Москва

- Light

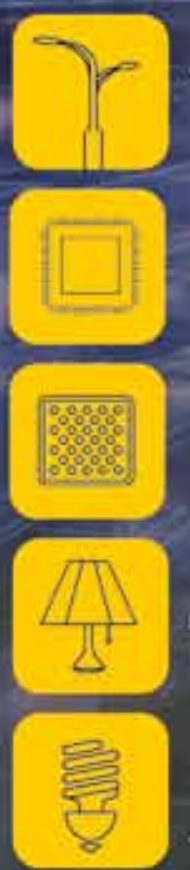

Декоративный свет

Электрические лампы

\section{Building}

Электротехника.

Умный дом

Автоматизация зданий

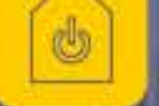

LED-технологии

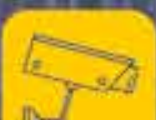

N

Интегрированные

системы безопасности

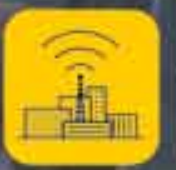

Умный город 